\title{
Estabilidad de variedades de trigo recomendadas para siembras de temporal en los Valles Ältos de la Mesa Central*
}

\section{Stability of wheat varieties recommended for rainfed cultivation in the high valleys of the Central Plateau}

\author{
René Hortelano Santa Rosa ${ }^{1 \S}$, Héctor Eduardo Villaseñor Mir ${ }^{1}$, Eliel Martínez Cruz ${ }^{1}$, María Florencia Rodríguez García ${ }^{1}$, \\ Eduardo Espitia Rangel ${ }^{2}$ y Luis Antonio Mariscal Amaro \\ ${ }^{1}$ Campo Experimental Valle de México, INIFAP. Carretera Los Reyes-Texcoco, 13.5. Coatlinchán, Texcoco Estado de México, C.P. 56250. Tel. 01 595 92 12657. Ext. 152, \\ 161,154y 153.(villasenor.hector@inifap.gob.mx),(martinez.eliel@onifap.gob.mcx),(rodriguez.maria@inifap.gob.mx).르. \\ Celaya-San Miguel de Allende, 6.5.C.P.38000, Celaya, Guanajuato, México.Tel.014616177107y 014616115323. (espitia.eduardo@inifap.gob.mx),(mariscal.luis@ \\ inifap.gob.mx). ${ }^{\S}$ Autor para correspondencia: hortelano.rene@inifap.gob.mx.
}

\section{Resumen}

Con el objetivo de estudiar el comportamiento agronómico, fitopatológico, calidad industrial y estabilidad del rendimiento de grano de 20 variedades de trigo harinero que se siembran bajo condiciones de temporal en la MesaCentraldeMéxico, se establecieron ensayos en 11 localidades delEstado de México que representan los ambientes de temporal de esta región. Se identificaron dos grupos de variedades, las de alto rendimiento y las de rendimiento moderado; en las primeras se ubicaron Chicalote "S", Rebeca F2000, Náhuatl F2000, Pastor F2000, Triunfo F2004 y Tlaxcala F2000. Las variedades generadas para siembras deriego para la región deElBajío no expresaron buena productividad y fueron susceptibles a enfermedades. Otras variedades como Era F2000, Finsi F2000, Batán F96, Juchi F2000, Pavón F76, Gálvez M87, Temporalera M87 y Zacatecas VT74, que fueron liberadas para siembras de temporal, ya no es conveniente que se siembren por sus bajos rendimientos y/o susceptibilidad a enfermedades. Rebeca F2000, Náhuatl F2000, Tlaxcala F2000, Triunfo F2004, Tollocan F05 y Pastor F2000 expresaron buena resistencia a las enfermedades foliares. Con base en la calidad, las variedades con mejores cualidades industriales fueron: Chicalote "S", Rebeca F2000, Náhuatl F2000, Triunfo

\section{Abstract}

With the aim of studying the agronomic and phytopathological behavior, as well as the industrial quality and grain yield stability of 20 bread wheat varieties that are grown under rainfed conditions in the Central Plateau of Mexico, we set up assays in 11 localities of the State of Mexico which are representative of the rainfed environments of this region. We identified two groups of varieties, one with high and the other with moderate yield; the first group included the varieties Chicalote "S", Rebeca F2000, Náhuatl F2000, Pastor F2000, Triunfo F2004 and Tlaxcala F2000. The varieties developed for irrigated cultivation in the region of El Bajío did not have a good yield and were susceptible to diseases. Other varieties, such as Era F2000, Finsi 2000, Batan F96, Juchi F2000, Pavón F76, Gálvez M87, Temporalera M87 and Zacatecas VT74, which were released for rainfed cultivation, are no longer suitable to be planted due to their low yield and/or susceptibility to diseases. Rebeca F2000, Náhuatl F2000, Tlaxcala F2000, Triunfo F2004, Tollocan F05, and Pastor F2000 showed good resistance against foliar diseases. The varieties with better industrial qualities were: Chicalote "S", Rebeca F2000, Náhuatl F2000, Triunfo F2004,

\footnotetext{
* Recibido: julio de 2012

Aceptado: febrero de 2013
} 
F2004, Tlaxcala F2000, Romoga F96, Tollocan, Gálvez M87, Finsi F2000, Era F2000 y Juchi F2000, siendo estas primeras cinco también las más estables.

Palabras clave: Triticum aestivum L., calidad panadera, interacción genotipo $\times$ ambiente.

\section{Introducción}

En México los productores que siembran maíz en la región de la Mesa Central en altitudes que van de los 2100 a $2800 \mathrm{msnm}$, cada vez tienen menos opciones de cultivo para competir ante un mercado globalizado, por lo que es conveniente que éstos cuenten con alternativas más rentables, con mercado seguro y diversificado. El trigo de temporal que se produce a nivel nacional, alcanzó una cifra de 166 mil hectáreas con una producción de 242 mil toneladas, mientas que en los estados del Altiplano Central en los últimos años, la superficie sembrada con este cultivo ha alcanzado las $56 \mathrm{mil}$ hectáreas en 2010 con una producción anual de 162 mil t y rendimiento promedio de $2.8 \mathrm{t} \mathrm{ha}^{-1}$ (SIAP, 2010).

Esta producción resulta atractiva ya que es obtenida cerca de los sitios de mayor consumo y de procesamiento de este cereal; no obstante que esos mismos sitios tienen condiciones de clima y suelo que permite producirlo en forma rentable en pocomás de 300 mil hectáreas (Turrentetal., 1992). El trigo de temporal es afectado por problemas bióticos que demeritan su rendimiento; además, las variedades liberadas con el tiempo se vuelven susceptibles a enfermedades, principalmente a la roya lineal amarilla (Puccinia striiformis f sp. tritici) y de la hoja (Puccinia Triticina), ya que estos patógenos presentan gran variabilidad de razas fisiológicas en México (Singh, 1991; Huerta y Singh, 2000) o porque se presentan nuevas razas que rompen la resistencia de las variedades (Singh et al., 2004).

En los ambientes donde se cultiva trigo de temporal en nuestro país se presenta inconsistencia de resultados debido a los contrastes entre sitios y años (Villaseñor y Espitia, 2000). Es por esto que en las estrategias de evaluación de generaciones de segregantes y variedades mejoradas se contempla la determinación de los entornos de producción, lo que permite generar información aplicable a otros ambientes con condiciones similares. Por lo que es preciso establecer ensayos en la mayor gama de ambientes para valorar el potencial de rendimiento y la estabilidad fenotípica de las variedades (Crossa, 1990).
Tlaxcala F2000, Romoga F96, Tollocan, Gálvez M87, Finsi F2000, Era F2000 and Juchi F2000: The first five of this list were also the more stable.

Keywords: Triticum aestivum L., baking quality, genotype $\times$ environment, interaction.

\section{Introduction}

In Mexico, growers planting corn on the Central Plateau region at altitudes of 2 100-2 800 masl have increasingly fewer options for competing in a global market, so it would be convenient for them to be able to rely on more profitable alternatives, ones with a secure and diversified market. The rainfed wheat produced in Mexico reached a figure of 166000 hectares, with a production of 242000 tonnes, while in recent years, in the Central Plateau states, the area planted with this crop reached 56000 hectares in 2010 with an annual production of $162000 \mathrm{t}$ and an average yield of 2.8 tha $^{-1}$ (SIAP, 2010).

Producing wheat in this region has the advantage of being near processing facilities and also near the sites where consumption is higher. Even though these region has climate and soil conditions allowing to profitably grow wheat in over 300000 hectares (Turrent et al., 1992), rainfed wheat is affected by biotic problems that affect crop yield; besides, released varieties eventually become susceptible to diseases, mainly to stripe rust (Puccinia striiformis $\mathrm{f}$ sp. tritici) and leaf rust (Puccinia Triticina), because these pathogens are present in a wide variety of physiological races in Mexico (Singh, 1991; Huerta and Singh, 2000), or because of the appearance of new breeds that overcome the resistance of the varieties (Singh et al., 2004).

In the environments where rainfed wheat is grown in Mexico, production results are inconsistent due to the contrasts between sites and years (Villaseñor and Espitia, 2000). That is why when developing an assessment strategy of segregating generations and improved varieties, it is necessary to consider the determining conditions of the production environments, which allows to generate information applicable to other environments with similar conditions. Therefore, it is necessary to establish assays in the widest range of environments possible in order to assess the yield potential and the phenotypic stability of the different varieties (Crossa, 1990). 
Para determinar la estabilidad se han generado diferentes metodologías, entre las que destacan la de Lin et al. (1986), quienes mencionaron que un genotipo es estable cuando; éste presenta mínima varianza entre ambientes, características que fueron destacadas por Finlay y Wilkinson(1963)y Shukla (1972); y cuando el cuadrado medio de las desviaciones de regresión del genotipo en cuestión sea pequeño, donde el índice ambiental se considera como variable independiente, que equivale al parámetro $S^{2} d i$ de Eberhart y Russell (1966) y al $\lambda i$ Tai (1971); y cuando se presentan variaciones pequeñas de un genotipo en una localidad pero en diferentes años. Ante este panorama es de gran importancia que los productores de trigo cuenten con variedades que tengan buena productividad, calidad industrial, estabilidad y adaptación, por lo que los objetivos de este estudio fueron: a) evaluar el rendimiento, características agronómicas y de calidad de variedades de trigo sembradas bajo condiciones contrastantes de temporal; b) determinar con base en sus características fitopatológicas que variedades fueron las más tolerantes; y c) medir la estabilidad del rendimiento de las variedades evaluadas en tales ambientes.

\section{Materiales y métodos}

Las 20 variedades evaluadas representan la diversidad genética que se ha venido utilizando en los ambientes de temporal y están clasificadas como suaves (S), medianas $(\mathrm{M})$, fuertes $(\mathrm{F})$ o tenaces $(\mathrm{T})$ con base a su tipo de gluten, generadas por el Instituto Nacional de Investigaciones Forestales, Agrícolas y Pecuarias (INIFAP) y el Centro Internacional de Maíz y Trigo (CIMMYT), incluidas nueve variedades liberadas en el periodo de 1974 a 1996, una línea avanzada sobresaliente y 10 liberadas durante 2000 a 2005 (Cuadro 1). El grupo de localidades de evaluación son representativas de la variabilidad ambiental que realizan las siembras de trigo de temporal en nuestro país, y en éstas se ha venido cultivando por más de cinco años durante el ciclo primavera-verano, y se clasifican como ambientes favorables e intermedios por su precipitación media anual que oscila de los 400 a $500 \mathrm{~mm}$.

Los genotipos se establecieron bajo el diseño experimental de bloques completos con tratamientos aleatorizados (DBCTA) con dos repeticiones. En todas las localidades la parcela experimental estuvo constituida por cuatro surcos separados a $0.3 \mathrm{~m} \times 3.0 \mathrm{~m}$ de longitud, siendo la parcela útil el total de la parcela experimental $\left(3.6 \mathrm{~m}^{2}\right) . \mathrm{La}$
Different methodologies have been developed to determine stability, among which stand out the one of Lin et al. (1986), who mentioned that a genotype is stable when it has minimal variance between environments, and when the mean square deviations from regression of the genotype in question are small, where the environmental index is considered as an independent variable, which equals the parameter $\mathrm{S}^{2} d i$ of Eberhart and Russell (1966) and the $\lambda i$ parameter of Tai (1971); and also when there are small variations of a genotype in the same locality but in different years, features that were highlighted by Finlay and Wilkinson (1963), and Shukla (1972).

Against this background, it is of great importance that wheat farmers have good yielding varieties, with good industrial qualities, stability and adaptive capacity. Thereby, the objectives of this study were: a) to evaluate the yield, the agronomic and quality characteristics of wheat varieties planted under contrasting rainfed conditions; $b$ ) to determine, based on their phytopathological characteristics, which varieties are the most tolerant; and c) to measure the yield stability of the varieties evaluated in such environments.

\section{Materials and methods}

The 20 varieties evaluated represent the genetic diversity that has been commonly used in rainfed environments; they are classified as soft (S), medium (M), strong (St) or tough (T), based on their type of gluten. These varieties were generated by the National Institute for Forestry, Agriculture and Livestock (INIFAP) and the International Center for Maize and Wheat (CIMMYT), including nine varieties released in the period 1974-1996, an outstanding advanced line, and 10 varieties released during 2000-2005 (Table 1). The group of evaluation locations are representative of the environmental variability in which the rainfed cultivation of wheat is carried out in Mexico; they have been planted with wheat for more than five years during the springsummer, and are classified as favorable and intermediate environments because of their annual rainfall ranging from 400-500 mm.

The genotypes were established under a Randomized Complete Block Design (RCBD) with two replicates. In all locations the experimental plot consisted of four rows spaced $0.3 \mathrm{~m} \times 3 \mathrm{~m}$ long; the useful plot was the total experimental plot $\left(3.6 \mathrm{~m}^{2}\right)$. Both planting and assays were carried out based 
siembra y conducción de los ensayos realizó con base en las recomendaciones generadas por el INIFAP para cada ambiente. Se tomaron las variables; días a espigamiento (DF), número de días transcurridos hasta que $50 \%$ de las espigas presentara las anteras visibles; días a madurez (DM), número de días transcurridos desde la siembra hasta $50 \%$ de la espigas presentaran pedúnculos amarillentos; altura de planta (AP), longitud en $\mathrm{cm}$ de la base de la planta hasta la espiguilla terminal en el dosel; y rendimiento de grano (REND) en $\mathrm{kg} \mathrm{ha}^{-1}$.

Para registrar la infeccione de las royas, se utilizó la escala visual propuesta por Roelfs et al. (1992). En forma simultánea se registraron datos de enfermedades foliares utilizando la escala visual de 0 a 9 de dígitos dobles (Saari y Prescott, 1975), la toma de datos posteriores se hicieron cada 15 días. Los parámetros de calidad determinados fueron: peso hectolítrico $(\mathrm{PH})$, obtenido por el peso en una unidad de volumen $\left(\mathrm{kg} \mathrm{hL}^{-1}\right)$ de una muestra de cada repetición, determinado en una balanza Winchester Bushel Meter o Ohaus (método 55-10,AACC, 1995); rendimiento harinero (Rhr), mediante la molienda de las muestra con un molino Buhler ; la proteína en grano (PG) se determinó con el analizador de infrarrojo cercano (NIR Feed \& Forage 5000) utilizando el método 39-00 de la AACC (2000), calibrando el equipo con el método Kjeldahl 46-11A (AACC, 1995); la dureza del grano (DG) se determinó por el método indirecto de índice de perlado, con una perladora tipo Strong Scot-EUA, colocando una muestra de $20 \mathrm{~g}$ de grano en el aparato por un minuto para obtener el porcentaje de grano perlado.

En harina refinada se midieron las variables: volumen de sedimentación (Vsd), que se obtuvo mediante las pruebas de Zeleny (Serna, 1996); la fuerza (W) y extensibilidad del gluten $(\mathrm{T} / \mathrm{L})$, evaluados sometiendo una muestra de cada repetición de $50 \mathrm{~g}$ de masa en un Alveógrafo tipo Chopin, con base al método 54-30A de la AACC (1995). El volumen de pan (VP) se obtuvo mediante el método de masa directa 10-09 (AACC, 1995). En variables fenotípicas, se realizó el análisis de varianza combinado con sus interacciones y una comparación de medias empleando la prueba de Tukey $(\alpha=$ $5 \%$ ). Adicionalmente se practicó un análisis de estabilidad para rendimiento de grano mediante estadísticos simples como la desviación estándar $(\mathrm{Si})$ y el coeficiente de variación (CVi)(Francis y Kannenberg, 1978), losíndices de estabilidad propuestos por Eberhart y Russell (1966) y los índices de superioridad de Lin y Binns (1988), utilizando el paquete SAS versión 9.2 para Windows (SAS-Institute, 2008). on the recommendations generated by the INIFAP for each environment. We considered the following variables: days to tasseling (DF); number of days until $50 \%$ of the spikes presented visible anthers; days to maturity (DM); number of days from planting to $50 \%$ of the spikes presenting yellowish stalks; plant height (AP), length in $\mathrm{cm}$ from the base of the plant to the terminal spikelet in the canopy; and grain yield (YIELD) in $\mathrm{kg} \mathrm{ha}^{-1}$.

Cuadro 1. Variedades de trigo harinero y localidades del Estado de México donde se establecieron los ensayos durante los ciclos primavera-verano, 2006 y 2007.

Table 1. Bread wheat varieties and localities of the State of Mexico where the assays were established during the spring-summer cycles of 2006 and 2007.

\begin{tabular}{|c|c|c|}
\hline \multicolumn{2}{|c|}{ Variedades $^{\dagger}$} & Localidades $^{\dagger \dagger}$ \\
\hline Tollocan F05 & Batán F96 & Calaveras 06 \\
\hline Triunfo F2004 & Romoga F96 & Calaveras 07 \\
\hline Barcenas S2002 & Eneida F94 & Chapingo 06 \\
\hline Era F2000 & Cortazar S94 & Chapingo 07 \\
\hline Finsi F2000 & Gálvez M87 & Coatepec 06 \\
\hline Juchi F2000 & Temporalera M87 & Coatepec 07 \\
\hline Náhuatl F2000 & Pavón F76 & El Llano 06 \\
\hline Pastor F2000 & Salamanca S75 & El Llano 07 \\
\hline Rebeca F2000 & Zacatecas VT74 & Santa Lucía 06 \\
\hline Tlaxcala F2000 & & Santa Lucía 07 \\
\hline Chicalote "S" & & Temamatla 07 \\
\hline
\end{tabular}

To record rust infections, we used the visual scale proposed by Roelfs et al. (1992). At the same time, we recorded foliar disease data using the 0-9 visual scoring scale (Saari and Prescott, 1975); subsequent data collections were made every 15 days. The quality parameters determined were: hectolitre weight (HG), obtained by the weight of a unit volume $\left(\mathrm{kg} \mathrm{hL}^{-1}\right)$ of a sample of each replicate, determined on a scale Winchester Bushel Meter or Ohaus (method 55-10, AACC, 1995); flour yield (Rhr), by grinding the sample with a Buhler mill; grain protein (GP), determined with a near infrared analyzer (NIR Feed \& Forage 5000) using the method 39-00 of the AACC (2000), calibrating the equipment with the method Kjeldahl 46-11A (AACC, 1995); hardness of the grain (DG), which was determined by the indirect method of the pearl index, with a Strong Scot pearler, placing a sample of $20 \mathrm{~g}$ of grain in the device for one minute to obtain the percentage of pearled grain. 


\section{Resultados y discusión}

En el Cuadro 2 se presenta el análisis de varianza combinado de las 11 localidades de evaluación. Se detectaron diferencias altamente significativas entre localidades, variedades y en la interacción localidad $\times$ variedad, en todas la variables evaluadas, aunque en esta última fuente de variación la variable altura de planta no fue significativa.
In refined flour we measured the following variables: sedimentation volume (Vsd), obtained by the Zeleny test (Serna, 1996); force (W) and extensibility of gluten (T/L), evaluated by subjecting a sample of $50 \mathrm{~g}$ of dough from each replicate into a Chopin Alveograph, based on the method 5430A of the AACC (1995). Bread volume (BV) was obtained by the straight dough method 10-09 (AACC, 1995). The phenotypic variables and their interactions were subjected to an analysis of variance, and their means were compared

Cuadro 2. Análisis de varianza general para cuatro variables registradas en 20 variedades de trigo, evaluadas en 11 ambientes de temporal. Ciclos primavera-verano, 2006 y 2007.

Table 2. General variance analysis for four variables of 20 wheat varieties evaluated in 11 rainfed environments. Springsummer cycles, 2006 and 2007.

\begin{tabular}{lcrrrr}
\hline FV & Gl & DF & DM & AP & REND \\
\hline Loc & 10 & $1372^{* *}$ & $3490^{* *}$ & $2493^{* *}$ & $33901819^{* *}$ \\
Rep (Loc) & 11 & 3.2 & 2.3 & 147 & 316519 \\
Var & 19 & $318^{* *}$ & $118^{* *}$ & $443^{* *}$ & $4935120^{* *}$ \\
Loc*Var & 190 & $5.9^{* *}$ & $6.1^{* *}$ & $28^{\text {ns }}$ & $620550^{* *}$ \\
Error & 209 & & 3.3 & 29.5 & 256739 \\
Total & 439 & & & & \\
CV $(\%)$ & & 2.5 & 1.5 & 6.6 & 15.1 \\
Media & & 64.5 & 116.2 & 81.7 & 3344.2 \\
\hline
\end{tabular}

$\mathrm{FV}=$ fuente de variación; $\mathrm{GL}=$ grados de libertad; $\mathrm{DF}=$ días a floración; $\mathrm{DM}=$ días a madurez; $\mathrm{AP}=$ altura de $\mathrm{planta} ; \mathrm{REND}=$ rendimiento $\left(\mathrm{kg}\right.$ ha $\left.{ }^{-1}\right)$.

Los coeficientes de variación reportados son bajos, por lo que los resultados se consideran como aceptables. Estos resultados revelan que los ambientes de producción de trigo harinero de temporal son muy contrastantes, que las variedades se comportan de diferente forma al ser cambiadas de ambiente y que las interacciones pueden ser aprovechadas detectando la adaptación que ciertas variedades presenta. En el Cuadro 3 se presenta la comparación de medias para las diferentes localidades de prueba, en donde se observa que el rendimiento varió de 2.1 a 4.8 t ha $^{-1}$, el ciclo de cultivo osciló de 105 a 136 días y la altura de planta varió de 66 a $93 \mathrm{~cm}$.

En las localidades donde se obtuvieron los mayores rendimientos también presentaron mayor altura de planta, aunque el ciclo fue muy semejante, excepto en la localidad de El Llano 06 y 07, donde en esta variable los genotipos exhibieron los mayores valores. La variación presentada en el rendimiento de grano se puede atribuir por un lado al potencial productivo de los ambiente, y por el otro al potencial genético en interacción con el primero, ya que se ha encontrado que el mayor número y tamaño de grano varía dependiendo del tiempo disponible del ciclo (Solís et al., 2004), y de la tasa de formación de grano (Slafer et al., 1996). using the Tukey test ( $\alpha=5 \%$ ). Additionally, a grain yield stability analysis was carried out using simple statistics such as the standard deviation $(\mathrm{Si})$ and the coefficient of variation (CVi) (Francis and Kannenberg, 1978), as well as the stability indexes proposed by Eberhart and Russell (1966) and the superiority indexes of Lin and Binns (1988), with use of the SAS software for Windows, version 9.2 (SAS Institute, 2008).

\section{Results and discussion}

Table 2 presents the combined analysis of variance of the 11 sites evaluated. Highly significant differences were detected between locations, varieties and the interaction location $\times$ variety in all the variables assessed, although in the latter source of variation the plant height variable was not significant.

The variation coefficients reported are low, so the results are considered as acceptable. These results reveal that the production environments of rainfed bread wheat are very contrasting, that the varieties behave differently when moved 
Cuadro 3. Variables registradas en 20 genotipos de trigo, evaluados en 11 localidades del Estado de México. Primaveraverano, 2006 y 2007.

Table 3. Variables recorded in 20 wheat genotypes, evaluated in 11 localities of the State of Mexico. Spring-summer, 2006 and 2007.

\begin{tabular}{lllll}
\hline Localidad & REND $\left(\mathrm{kg} \mathrm{ha}^{-1}\right)$ & DF $($ días $)$ & DM $($ días $)$ & AP $(\mathrm{cm})$ \\
\hline Santa Lucia 07 & $4824 \mathrm{a}$ & $58.2 \mathrm{~g}$ & $111 \mathrm{~g}$ & $87 \mathrm{abc}$ \\
El Llano 06 & $4662 \mathrm{a}$ & $72.7 \mathrm{a}$ & $129 \mathrm{~b}$ & $93 \mathrm{a}$ \\
Chapingo 07 & $3915 \mathrm{~b}$ & $61.1 \mathrm{ef}$ & $110 \mathrm{~g}$ & $91 \mathrm{a}$ \\
Coatepec 07 & $3582 \mathrm{bc}$ & $59.7 \mathrm{fg}$ & $113 \mathrm{f}$ & $81 \mathrm{bcd}$ \\
Chapingo 06 & $3555 \mathrm{bc}$ & $61.5 \mathrm{de}$ & $104 \mathrm{~h}$ & $81 \mathrm{bcd}$ \\
El Llano 07 & $3523 \mathrm{bc}$ & $66.9 \mathrm{c}$ & $136 \mathrm{a}$ & $83 \mathrm{abcd}$ \\
Santa Lucía 06 & $3279 \mathrm{c}$ & $63.1 \mathrm{~d}$ & $105 \mathrm{~h}$ & $76 \mathrm{cde}$ \\
Calaveras 06 & $2757 \mathrm{~d}$ & $67.1 \mathrm{c}$ & $115 \mathrm{e}$ & $76 \mathrm{de}$ \\
Temamatla 07 & $2311 \mathrm{de}$ & $56.1 \mathrm{~h}$ & $116 \mathrm{e}$ & $66 \mathrm{f}$ \\
Calaveras 07 & $69.5 \mathrm{~b}$ & $123 \mathrm{c}$ & $-\dagger$ \\
Coatepec 06 & $2242 \mathrm{e}$ & $73.5 \mathrm{a}$ & $117 \mathrm{~d}$ & $84 \mathrm{abcd}$ \\
Tukey $(\alpha=0.05 \%)$ & $2137 \mathrm{e}$ & 1.5 & 1.3 & 10.7 \\
\hline
\end{tabular}

‘No se contó con el dato de la variable en esa localidad; medias con la misma letra en cada columna no son significativamente diferentes.

En el Cuadro 4 se presenta el rendimiento de grano y el comportamiento agronómico de las variedades, siete variedades comerciales y la línea Chicalote "S" fueron los genotipos con rendimiento de grano estadísticamente superiores, aunque semejantes al mejor testigo Rebeca F2000, esta línea fue superior a las variedades testigo Náhuatl F2000, Pastor F200, Triunfo F2004, Tlaxcala F2000, Tollocan F05 y Romoga F96, siendo la diferencia con las últimas dos variedades hasta $16 \%$, y con las variedades menos rendidoras Bárcenas S2002 y Salamanca S75 hasta de $30 \%$.

Las variedades de bajo rendimiento presentaron problemas importantes asociadas a la incidencia de enfermedades, las generadas para riego de El Bajío (Salamanca S75, Cortazar S94, Eneida F94 y Bárcenas S2002) mostraron su inadaptabilidad en siembras de temporal, ya que la vida útil de las variedades depende, entre otras causas, de la durabilidad de su resistencia (McIntosh, 1992), por lo que si la resistencia de una variedad se basa y en sólo un gen de efectos mayores o es de raza específica, la resistencia se estima en tres años en las condiciones de nuestro país (Singh et al., 2000), de ahí que es deseable que una determinada variedad que tenga en su patrimonio genético varios genes to another environment, and that the interactions can be exploited by determining the adaptive capacity of certain varieties. Table 3 shows the comparison of means for the different test sites, where it is observed that the yield varied from 2.1 to $4.8 \mathrm{t} \mathrm{ha}^{-1}$, that the growing cycle ranged from 105 to 136 days and that plant height ranged from 66 to $93 \mathrm{~cm}$.

In the localities where the highest yields were obtained, the plants attained also greater heights, although the cycle was very similar, except in the localities of El Llano 06 and 07, where the genotypes exhibited the highest values of this variable. The variation in grain yield can be attributed, on one hand, to the production potential of the environment, and, on the other hand, to the interaction of the genetic potential with the production potential, since it has been found that greatest amount and size of the grains varies depending on the cycle time available (Solis et al., 2004) and the grain formation rate (Slafer et al., 1996).

Table 4 shows the grain yield and the agronomic behavior of all the varieties. Seven commercial varieties, and the Chicalote "S" line were the genotypes with statistically highest grain yield, though it was similar to that of the best 
de resistencia de efectos menores o cuantitativos para que posea un periodo de vida más largo en siembras comerciales (Milus y Line, 1986). control Rebeca F2000, which was superior in this regard to the control varieties Náhuatl F2000, Pastor F200, Triunfo F2004, TlaxcalaF2000, Tollocan F05, and Romoga F96; the

Cuadro 4. Variables evaluadas, reacción a royas y enfermedades foliares en 20 variedades de trigo, promedio de 11 ambientes de temporal. Primavera-verano, 2006 y 2007.

Table 4. Variables evaluated, reaction to rusts and foliar diseases in 20 varieties of wheat; average from 11 rainfed environments. Spring-summer, 2006 and 2007.

\begin{tabular}{|c|c|c|c|c|c|c|c|c|c|c|}
\hline \multirow[t]{2}{*}{ Variedad } & \multirow{2}{*}{$\frac{\text { REND }}{\left(\mathrm{kg} \mathrm{ha}^{-1}\right)}$} & \multirow{2}{*}{$\begin{array}{c}\text { DF } \\
\text { (días) }\end{array}$} & \multirow{2}{*}{$\frac{\mathrm{DM}}{\text { (días) }}$} & \multirow{2}{*}{$\begin{array}{l}\text { ALT } \\
(\mathrm{cm})\end{array}$} & \multicolumn{3}{|c|}{2006} & \multicolumn{3}{|c|}{2007} \\
\hline & & & & & $\mathrm{Yr}$ & $\mathrm{Lr}$ & Fol & $\mathrm{Yr}$ & $\mathrm{Lr}$ & Fol \\
\hline Chicalote "S" & $4411 \mathrm{a}$ & $66 \mathrm{bc}$ & $116 \mathrm{de}$ & $89 a b$ & $10 \mathrm{R}$ & $10 \mathrm{MR}$ & $5 / 30$ & $\mathrm{TR}$ & $15 \mathrm{MR}$ & $6 / 30$ \\
\hline Rebeca F2000 & $4293 \mathrm{a}$ & $71 \mathrm{a}$ & $122 \mathrm{a}$ & $90 \mathrm{a}$ & $50 \mathrm{MS}$ & 0 & $4 / 20$ & $60 \mathrm{~S}$ & $5 \mathrm{MR}$ & $5 / 20$ \\
\hline Náhuatl F2000 & $4213 \mathrm{a}$ & $64 d$ & $114 \mathrm{fg}$ & $87 \mathrm{abc}$ & $10 \mathrm{MR}$ & $10 \mathrm{MR}$ & $7 / 50$ & $40 \mathrm{MS}$ & $20 \mathrm{MR}$ & $7 / 60$ \\
\hline Pastor F2000 & $4100 \mathrm{ab}$ & $70 \mathrm{a}$ & $119 \mathrm{bc}$ & 80 defg & $50 \mathrm{MS}$ & 0 & $5 / 20$ & $60 \mathrm{~S}$ & $10 \mathrm{MR}$ & $6 / 30$ \\
\hline Triunfo F2004 & $3994 \mathrm{ab}$ & $64 \mathrm{~cd}$ & $116 \mathrm{def}$ & $82 \mathrm{cdef}$ & $10 \mathrm{MR}$ & $15 \mathrm{MR}$ & $7 / 30$ & $20 \mathrm{MR}$ & $20 \mathrm{MR}$ & $7 / 40$ \\
\hline Tlaxcala F2000 & $3960 \mathrm{abc}$ & 62 efg & 116 def & 80 def & $15 \mathrm{MR}$ & $20 \mathrm{MR}$ & $7 / 30$ & $30 \mathrm{MR}$ & $20 \mathrm{MR}$ & $7 / 50$ \\
\hline Tollocan F05 & $3720 \mathrm{bcd}$ & $70 \mathrm{a}$ & $119 b c$ & 82 cdef & $30 \mathrm{MS}$ & TR & $7 / 30$ & $40 \mathrm{MS}$ & $10 \mathrm{MR}$ & $7 / 40$ \\
\hline Romoga F96 & $3698 \mathrm{bcd}$ & $65 \mathrm{~cd}$ & $117 \mathrm{~d}$ & $81 \mathrm{def}$ & 20MR & $20 \mathrm{MR}$ & $7 / 50$ & $30 \mathrm{MR}$ & $30 \mathrm{MR}$ & $7 / 60$ \\
\hline Era F2000 & 3499 cde & $64 \mathrm{~cd}$ & 116 def & 84 bcde & $5 \mathrm{R}$ & $\mathrm{TR}$ & $5 / 30$ & $15 \mathrm{MR}$ & $15 \mathrm{MR}$ & $7 / 40$ \\
\hline Gálvez M87 & $3471 \mathrm{de}$ & 59 hi & $114 \mathrm{~g}$ & 83 cde & $60 \mathrm{~S}$ & $60 \mathrm{~S}$ & $7 / 80$ & $70 \mathrm{~S}$ & $60 \mathrm{~S}$ & $7 / 90$ \\
\hline Pavón F76 & 3452 de & $67 b$ & $118 \mathrm{~cd}$ & 84 bcde & $40 \mathrm{~S}$ & $60 \mathrm{~S}$ & $7 / 80$ & $70 \mathrm{~S}$ & $60 \mathrm{~S}$ & $7 / 80$ \\
\hline Juchi F2000 & $3451 \mathrm{de}$ & $65 \mathrm{~cd}$ & $117 \mathrm{de}$ & $84 \mathrm{ab}$ & $10 \mathrm{R}$ & $50 \mathrm{MS}$ & $7 / 30$ & $20 \mathrm{MR}$ & $60 \mathrm{~S}$ & $7 / 60$ \\
\hline Batán F96 & $3435 \mathrm{de}$ & $63 \mathrm{de}$ & 115 efg & $81 \mathrm{def}$ & $30 \mathrm{~S}$ & $50 \mathrm{~S}$ & $7 / 30$ & $70 \mathrm{~S}$ & $60 \mathrm{~S}$ & $7 / 50$ \\
\hline Finsi F2000 & $3405 \mathrm{de}$ & $70 a$ & $120 \mathrm{ab}$ & 80 defg & $10 \mathrm{R}$ & $10 \mathrm{MR}$ & $3 / 10$ & $20 \mathrm{MR}$ & $15 \mathrm{MR}$ & $4 / 30$ \\
\hline Temporalera M87 & $3382 \mathrm{de}$ & $66 \mathrm{~b}$ & $117 \mathrm{~d}$ & $86 \mathrm{abcd}$ & $80 \mathrm{~S}$ & $60 \mathrm{~S}$ & $5 / 40$ & $80 \mathrm{~S}$ & $70 \mathrm{~S}$ & $6 / 50$ \\
\hline Cortazar S94 & $3325 \mathrm{de}$ & $58 \mathrm{i}$ & $114 \mathrm{fg}$ & $76 \mathrm{fgh}$ & $20 \mathrm{MS}$ & $40 \mathrm{~S}$ & $7 / 70$ & $60 \mathrm{~S}$ & $40 \mathrm{~S}$ & $7 / 80$ \\
\hline Eneida F94 & $3305 \mathrm{de}$ & $61 \mathrm{fgh}$ & 115 efg & 78 efg & $10 \mathrm{MR}$ & $20 \mathrm{MR}$ & $7 / 100$ & $30 \mathrm{MS}$ & $30 \mathrm{MR}$ & $7 / 100$ \\
\hline Zacatecas VF74 & 3117 e & 60 ghi & $113 \mathrm{~g}$ & 79 efg & $30 \mathrm{MS}$ & $30 \mathrm{~S}$ & $7 / 70$ & $60 \mathrm{MS}$ & $40 \mathrm{MS}$ & $7 / 80$ \\
\hline Barcenas S2002 & $3085 \mathrm{e}$ & 60 hi & $113 \mathrm{~g}$ & $71 \mathrm{~h}$ & $30 \mathrm{MR}$ & $20 \mathrm{MR}$ & $7 / 70$ & $30 \mathrm{MR}$ & $30 \mathrm{MR}$ & $7 / 90$ \\
\hline Salamanca S75 & $3084 \mathrm{e}$ & $62 \mathrm{ef}$ & $113 \mathrm{~g}$ & $74 \mathrm{gh}$ & $40 \mathrm{MS}$ & $30 \mathrm{MR}$ & $7 / 100$ & $60 \mathrm{MS}$ & $20 \mathrm{MR}$ & $7 / 100$ \\
\hline Tukey (0.05) & 548.4 & 1.7 & 2 & 10.7 & & & & & & \\
\hline
\end{tabular}

$\mathrm{REND}=$ rendimiento; $\mathrm{DF}=$ días a floración; $\mathrm{DM}=$ días a madurez; $\mathrm{ALT}=$ altura de planta.

En el Cuadro 4 se presenta la respuesta de los genotipos a las royas y a enfermedades foliares. Las variedades que presentaron en buena resistencia fueron Chicalote "S", Triunfo F2004, Náhuatl F2000, Tlaxcala F2000, Tollocan F05 y Romoga F96 y mostraron mayor rendimiento. Las variedades Rebeca F2000 y Pastor F2000 mostraron alto rendimiento $\left(>3500 \mathrm{~kg} \mathrm{ha}^{-1}\right)$ pero también una alta susceptibilidad a la roya lineal amarilla (Yr), hecho que corrobora que los patógenos ya superaron la resistencia de las variedades Era F2000 y Finsi F2000 que tuvieron menores rendimientos, mientras que el resto de las variedades, por su susceptibilidad a royas y enfermedades foliares, es conveniente que ya no se recomienden para siembras difference with the last two varieties is around $16 \%$, and with the less yielding varieties Bárcenas S2002 and Salamanca $\mathrm{S} 75$, the difference is as big as $30 \%$.

The low-yielding varieties had significant problems associated with the incidence of diseases; the varieties developed for irrigated cultivation in El Bajío (Salamanca S75, Cortazar S94, Eneida F94, and Barcenas S2002) showed a lack of adaptability to rainfed cultivation, as the life of a variety depends, among other factors, on the durability of its resistance (McIntosh, 1992), so that if the resistance of a variety is based on a single major-effect gene or is race-specific, it would have an estimated resistance of 
comerciales de temporal, sobre todo Juchi F2000, Gálvez M87, PavónF76, Cortazar S94, Batán F96, Zacatecas VT74, Temporalera M87 y Salamanca S75.

Ante esta problemática, para cada ambiente de producción se recomiendan sólo aquellas que puedan competir con la variabilidad genética de estos patógenos (Rodríguez et al., 2010). De tal manera que con base en el rendimiento de grano, se ubicaron dos grupos de variedades; el primero formado por las que superaron las $3.5 \mathrm{tha}^{-1}$, en donde se ubican RebecaF2000, Chicalote "S", Náhuatl F2000, Pastor F2000, Triunfo F2004, Tlaxcala F2000, Tollocan F05 y Romoga F96, y el segundo con un rendimiento promedio de $3 \mathrm{t} \mathrm{ha}^{-1}$, constituido por EraF2000, Juchi F2000, Gálvez M87, Pavón M87, Cortazar S94, Finsi F2000 y Batán F96. Las variedades restantes presentan desventajas importantes y significativas que las descarta como opciones de siembra en temporal.

En el Cuadro 5 se presentan las características de calidad industrial. En el caso del peso hectolítrico (PH), éste es aceptable en todas las variedades. La variación en este parámetro llego a ser de $13.4 \%$ entre el menor y mayor valor, que correspondieron a las variedades Eneida F94 y Finsi F2000, respectivamente. three years under the conditions found in Mexico (Singh et $a l ., 2000)$. Hence, it is desirable that a particular variety with several minor-effect resistance genes has a longer lifetime in commercial plantings (Milus and Line, 1986).

Table 4 shows the response of the genotypes to rust and foliar diseases. The varieties that showed good resistance were Chicalote "S", Triunfo F2004, Náhuatl F2000, Tlaxcala F2000, Tollocan F05, and Romoga F96; they are also the ones that showed better grain yield. The varieties Rebeca F2000 and Pastor F2000 showed high yield (> 3 $500 \mathrm{~kg} \mathrm{ha}^{-1}$ ) but also a high susceptibility to the stripe rust (Yr), a fact that confirms that pathogens have overcome the resistance of the varieties Era F2000 and Finsi F2000, which had lower yields. The other varieties, given their susceptibility to rust and foliar diseases, should no longer be recommended for commercial rainfed cultivation, especially Juchi F2000, Gálvez M87, Pavón F76, Cortazar S94, Batan F96, Zacatecas VT74, Temporalera M87, and Salamanca S75.

Due to this problem, it is recommended that only the varieties that can compete with the genetic variability of the pathogens present in each production environment be

Cuadro 5. Calidad industrial de variedades de trigo evaluadas en cinco ambientes de temporal durante el ciclo primaveraverano, 2006 y 2007.

Table 5. Industrial quality of wheat varieties evaluated in five rainfed environments during the spring-summer cycle, 2006 and 2007.

\begin{tabular}{lccccccc}
\hline Variedad & PH & DG & Rhr & PG & W & T/L & VP \\
\hline Chicalote "S" & 78.4 & 52 & 73 & 9.0 & 292 & 3.3 & 770 \\
Rebeca F2000 & 78.8 & 45 & 70 & 9.3 & 456 & 2.6 & 685 \\
Náhuatl F2000 & 75.6 & 36 & 71 & 10.4 & 522 & 1.8 & 780 \\
Pastor F2000 & 76.4 & 39 & 69 & 9.4 & 520 & 2.3 & 715 \\
Triunfo F2004 & 79.2 & 42 & 72 & 10.1 & 500 & 2.4 & 710 \\
Tlaxcala F2000 & 78.4 & 41 & 67 & 10.4 & 510 & 2.2 & 725 \\
Temporalera M87 & 77.6 & 45 & 73 & 8.6 & 230 & 1.6 & 735 \\
Romoga F96 & 80.0 & 41 & 70 & 9.9 & 418 & 2.6 & 785 \\
Tollocan F05 & 75.6 & 44 & 65 & 9.7 & 229 & 2.5 & 765 \\
Batán F96 & 70.4 & 41 & 66 & 9.7 & 279 & 2.8 & 760 \\
Pavón F76 & 78.0 & 35 & 69 & 8.9 & 293 & 3.2 & 745 \\
Gálvez M87 & 74.8 & 58 & 67 & 9.6 & 239 & 0.74 & 825 \\
Finsi F2000 & 80.4 & 44 & 72 & 10.0 & 402 & 2.8 & 795 \\
Era F2000 & 77.6 & 41 & 67 & 10.8 & 438 & 2.4 & 770 \\
Eneida F94 & 69.6 & 61 & 68 & 10.0 & 197 & 1.5 & 735 \\
Juchi F2000 & 79.6 & 42 & 71 & 10.2 & 400 & 2.5 & 775 \\
Salamanca S75 & 70.8 & 55 & 66 & 9.6 & 202 & 1.2 & 770 \\
Cortazar S94 & 75.2 & 45 & 69 & 10.7 & 128 & 0.8 & 790 \\
Bárcenas S2002 & 72.0 & 63 & 65 & 10.2 & 163 & 0.6 & 845 \\
Zacatecas VT74 & 74.8 & 40 & 67 & 10.0 & 417 & 2.6 & 800 \\
\hline PH= peso hectolítrico; DG= dureza en grano; Rhr= rendimiento harinero; PG= proteína en grano; W= fuerza de gluten; T/L=índice de tenacidad; VP=volumende pan.
\end{tabular}


La dureza del grano (DG) ubicó a la mayoría de variedades como de grano duro a semiduro, con valores de 39 a 47, siendo las variedades Náhuatl F2000 y Pavón F76 las que presentaron menor índice de dureza $(<38.0)$, en tanto que las variedades Salamanca S75, Gálvez M87, Eneida F94, Barcenas S2002 y la línea Chicalote "S", fueron de grano suave ya que presentaron valores $>55$ en esa variable, mientras que la mayoría de los genotipos se mantuvieron en el rango de grano duro a semiduro, con índice de dureza de 39 a 47. La fluctuación entre genotipos en ésta variables fue de $44 \%$.

La variación entre genotipos en estas variables es atribuida principalmente al efecto de las localidades de acuerdo con lo reportado por Espitia et al. (2003 y 2004). El rendimiento harinero (Rhr) está muy relacionado con el PH (Peña et al., 2008), cualidad que es de suma importancia para la industria molinera. E1 $50 \%$ de los genotipos presentaron rendimiento harinero con valor $<70$, donde se ubican Salamanca S75, Cortazar S94, Eneida F94 y Barcenas S2002, variedades recomendadas para zonas de riego y otras que son para temporal (Cuadro 5).

En Alveograma W se tuvieron valores de 128 a 522. Sólo las variedades Cortazar S94, Barcenas S2002 y Eneida F94 tuvieron valores de $\mathrm{W}<200$, por lo que se clasifican como de gluten débil. Siete variedades presentaron valores de W en el rango de 200 a 300 , que corresponde a genotipos con tipo de gluten medio-fuerte, mientras que $50 \%$ de los materiales estudiados tuvieron gluten fuerte. (Cuadro 5). En otros estudios que han involucrado variedades para temporal, se ha encontrado que en este parámetro presenta una alta heredabilidad $\left(\mathrm{h}^{2}=0.70\right)($ Espitia et al., 2004), por lo que es factible realizar mejoras en este carácter ya que la variación encontrada se debió a efectos genéticos.

El índice de tenacidad-extensibilidad (T/L) osciló de 0.6 a 3.3 (Cuadro 5), dos variedades se mostraron como extensibles (Barcenas S2002, Gálvez M87), dos de tipo balanceado (Cortazar S94 y Salamanca S75), mientras que el resto fueron tenaces. Estos resultados concuerdan con los obtenidos por López et al. (2001), quienes reportan que para una misma variedad, en diferentes años, se presentaron variaciones en los parámetros de alveograma $\mathrm{W}, \mathrm{T} / \mathrm{L}$ y V. La variación volumen de pan (VP) no fue muy amplia, y 18 de las variedades estudiadas $(90 \%)$ fueron de buena calidad ( $\mathrm{VP}=700-800)$, y sólo las variedades Gálvez M87 y Bárcenas S2002 tuvieron muy buena calidad al superar las 800 unidades (Cuadro 5). Estos resultados concuerdan recommended for planting (Rodríguez et al., 2010). Thus, two groups of varieties were defined based on grain yield; the first comprised the varieties that exceeded $3.5 \mathrm{tha}^{-1}$ : Rebeca F2000, Chicalote "S", Náhuatl F2000, Pastor F2000, Triunfo F2004, TlaxcalaF2000, Tollocan F05, and Romoga F96; the second comprises the varieties that have an average yield of 3 t ha ${ }^{-1}$ : Era F2000, Juchi F2000, Gálvez M87, Pavón M87, Cortazar S94, Finsi F2000, and Batan F96.The remaining varieties have significant disadvantages that disqualify them as options for rainfed cultivation.

Table 5 presents the industrial quality characteristics. The hectolitre weight (HW) was acceptable in all varieties. The variation of this parameter was up to $13.4 \%$ between the lowest and the highest values, corresponding to the varieties Eneida F94 and Finsi F2000, respectively.

With respect to hardness of the grain (HG) most varieties had soft and semi-hard grains, with values of 39-47; the varieties Náhuatl F2000 and Pavón F76 showed the lowest hardness values $(<38.0)$, while the varieties Salamanca S75, Gálvez M87, Eneida F94, Barcenas S2002 and the line Chicalote "S" had soft grains, with values $>55$. Most of the genotypes were in the range of hard to semi-hard grains, with hardness values of between 39 and 47 . The fluctuation between genotypes with respect to this variable was $44 \%$.

The variation between genotypes in these variables is attributed mainly to the effect of the localities, in accordance with what was reported by Espitia et al. (2003 and 2004). Flour yield (Rhr) is closely related to HW (Peña et al. , 2008), a quality that is of paramount importance to the milling industry $.50 \%$ of the genotypes had a flour yield with a value lower than 70, including Salamanca S75, Cortazar S94, Eneida F94, Barcenas S2002, varieties recommended for irrigated areas, and others that are recommended for rainfed cultivation(Table 5).

The Alveogram W showed values between 128 and 522 . Only the varieties Cortazar S94, Barcenas S2002 and Eneida F94 had values of $\mathrm{W}<200$, so they were classified as having weak gluten. Seven varieties presented $\mathrm{W}$ values in the range of 200-300, corresponding to genotypes of mediumstrong gluten type, while $50 \%$ of the materials studied had strong gluten (Table 5). In other studies that have involved rainfed varieties, it has been found that this parameter has a high heritability $\left(\mathrm{h}^{2}=0.70\right)$ (Espitia et al., 2004), making it feasible to realize improvements with respect to it, as the variation found was due to genetic effects. 
con lo reportado por Espitia et al. (2004), quienes también encontraron poca variabilidad en este carácter pero con asociación significativa y positiva con la cantidad y calidad de las proteínas en el gluten.

De acuerdo con los estadísticos simples coeficiente de variación $\left(\mathrm{CV}_{\mathrm{i}}\right)$ y desviación estándar $\left(\mathrm{S}_{\mathrm{i}}\right)$, considerando que valores pequeños de estos representan una mayor estabilidad (Francis y Kannenberg, 1978), y los genotipos deseables serían los de mayor rendimiento y menor coeficiente de variación. La variedad Chicalote "S" es la más estable, seguida de Rebeca F2000, Náhuatl F2000, Pastor F2000, Triunfo F2004 y Tlaxcala F2000 (Cuadro 6). Los parámetros de estabilidad de Eberhart y Russell (1966) dieron como resultado coeficientes de regresión menores a la unidad en las variedades Salamanca S75, Barcenas S2002, Zacatecas VT74, Eneida F94 y Pavón M87, indicando que estas variedades presentan adaptación relativa a ambientes desfavorables (Rodríguez et al. 2002).
The tenacity-extensibility index $(\mathrm{T} / \mathrm{L})$ ranged from 0.6 to 3.3 (Table 5); two varieties were shown to be extensible (Barcenas S2002, Gálvez M87), two varieties were of the balanced type (Cortazar S94 and Salamanca S75), while the rest were tenacious. These results agree with those obtained by López et al. (2001), who reported that, for the same variety, in different years, there were variations in the alveogram parameters $\mathrm{W}, \mathrm{T} / \mathrm{L}$ and $\mathrm{V}$. The variation in bread volume (BV) was not very wide, and 18 of all the varieties studied $(90 \%)$ were of good quality $(\mathrm{BV}=700-800)$, and only the varieties Gálvez M87 and Barcenas S2002 were of very good quality, with over 800 units (Table 5). These results agree with those reported by Espitia et al. (2004), who also found little variability with respect to this character, but with a significant positive association with the quantity and quality of proteins in gluten.

With respect to the simple statistics coefficient of variation $\left(\mathrm{CV}_{\mathrm{i}}\right)$ and standard deviation $\left(\mathrm{S}_{\mathrm{i}}\right)$, small values represent greater stability (Francis and Kannenberg, 1978), and the

Cuadro 6. Parámetros de estabilidad de 20 variedades de trigo evaluadas en once ambientes de temporal. Primaveraverano, 2006 y 2007.

Table 6. Stability parameters of 20 wheat varieties evaluated in eleven rainfed environments. Spring-summer, 2006 and 2007.

\begin{tabular}{|c|c|c|c|c|c|c|c|}
\hline \multirow[t]{2}{*}{ Variedad } & \multirow[t]{2}{*}{ Rend. $\left(\mathrm{kg} \mathrm{ha}^{-1}\right)$} & \multirow[t]{2}{*}{$S i^{\dagger}$} & \multirow[t]{2}{*}{$\mathrm{CVi}(\%)^{\dagger \dagger}$} & \multicolumn{2}{|c|}{ Eberhart y Russell } & \multicolumn{2}{|c|}{ Lin y Binns } \\
\hline & & & & $\beta \mathrm{i}$ & $\mathrm{S}^{2} \operatorname{di}\left(10^{3}\right)$ & $\mathrm{Pi}\left(10^{4}\right)$ & $\mathrm{CM}(\mathrm{GxA})\left(10^{4}\right)$ \\
\hline Chicalote "S" & $4411 \mathrm{a}$ & 1264 & 28.4 & 0.96 & 208.9 & 19.0 & 8.3 \\
\hline Rebeca F2000 & $4293 \mathrm{a}$ & 1327 & 30.9 & 1.05 & 186.5 & 34.6 & 18.5 \\
\hline Náhuatl F2000 & $4213 \mathrm{a}$ & 1346 & 31.9 & 1.16 & -33.0 & 35.4 & 13.8 \\
\hline Pastor F2000 & $4100 \mathrm{ab}$ & 1256 & 30.6 & 1.02 & 65.4 & 50.6 & 21.3 \\
\hline Triunfo F2004 & $3994 \mathrm{ab}$ & 1277 & 32.0 & 1.08 & 18.5 & 53.0 & 14.1 \\
\hline Tlaxcala F2000 & $3960 \mathrm{abc}$ & 1208 & 30.5 & 1.05 & -1.1 & 62.6 & 21.4 \\
\hline Tollocan F05 & $3720 \mathrm{bcd}$ & 1244 & 33.4 & 1.00 & 61.3 & 75.4 & 7.6 \\
\hline Romoga F96 & $3698 \mathrm{bcd}$ & 1198 & 32.4 & 1.06 & -69.8 & 82.3 & 12.5 \\
\hline Era F2000 & 3499 cde & 1126 & 32.2 & 0.97 & 29.7 & 106.6 & 11.0 \\
\hline Gálvez M87 & $3471 \mathrm{de}$ & 1325 & 38.2 & 1.11 & 22.3 & 125.0 & 30.1 \\
\hline Pavón M87 & 3452 de & 1182 & 34.2 & 0.95 & -101.6 & 118.8 & 19.2 \\
\hline Juchi F2000 & $3451 \mathrm{de}$ & 1172 & 34.0 & 0.99 & 22.7 & 127.3 & 26.3 \\
\hline Batán F96 & 3435 de & 1246 & 36.3 & 1.09 & -138.4 & 119.3 & 14.9 \\
\hline Finsi F2000 & 3405 de & 1327 & 39.0 & 1.05 & 304.8 & 134.3 & 23.4 \\
\hline Temporalera M87 & $3382 \mathrm{de}$ & 1386 & 41.0 & 0.99 & -1.8 & 137.9 & 26.7 \\
\hline Cortázar S94 & $3325 \mathrm{de}$ & 1203 & 36.2 & 1.04 & -31.0 & 146.6 & 26.6 \\
\hline Eneida F94 & $3305 \mathrm{de}$ & 1204 & 36.4 & 0.94 & 72.9 & 157.1 & 34.7 \\
\hline Zacatecas VT74 & 3117 e & 1137 & 36.5 & 0.92 & 3.9 & 185.7 & 25.7 \\
\hline Barcenas S2002 & $3085 \mathrm{e}$ & 1069 & 34.6 & 0.81 & -83.0 & 184.6 & 24.0 \\
\hline Salamanca S75 & $3084 \mathrm{e}$ & 1106 & 35.9 & 0.75 & 40.6 & 190.0 & 34.3 \\
\hline & $3622^{\natural}$ & & & & & $74.2^{\text {था }}$ & $75.9^{\S}$ \\
\hline
\end{tabular}


Diezvariedades tuvieron valores 0.96 a 1.05 , considerándose como genotipos con rendimientos estables a través de ambientes y años, mientras que las variedades Romoga F96, Triunfo F2004, Batán F96, Gálvez M87 y Náhuatl F2000 presentaron coeficientes de regresión mayores que la unidad. indicando que tales variedades responden de forma positiva a la mejoras ambientales de producción. Las varianzas de las desviaciones de regresión $\left(\mathrm{S}^{2} \mathrm{di}\right)$ mostraron, para todos los casos, ser diferentes de cero, lo que indica que el modelo lineal no es el apropiado para describir la respuesta de los genotipos en función del efecto ambiental, ya que según este criterio, los genotipos no son estables debido a variaciones impredecibles. Nueve variedades tuvieron los menores valores en este parámetro entre las que destacan Náhuatl F2000, Temporalera M87, Tlaxcala F2000, Triunfo F2004, Gálvez M87 y Juchi F2000.

De acuerdo a los parámetros de superioridad de Lin y Binns (1988), los genotipos más estables fueron los que presentaron valores pequeños de $\mathrm{Pi}$, como son las variedades Chicalote “S”, Rebeca F2000, Náhuatl F2000, Pastor F2000, Triunfo F2004 y Tlaxcala F2000, clasificación que coincidió con la obtenida mediante el coeficiente de variación de Francis y Kannenberg (1978); éstas variedades también fueron las que mostraron los mayores rendimientos superando en amplio margen el rendimiento promedio general.

Por otro lado, analizando tales índices las variedades presentaron comportamiento paralelo a la máxima respuesta a través de ambientes, siendo los genotipos con mayor rendimiento por lo que este índice asigna estabilidad a altos rendimientos; además, presentaron valores menores en el parámetro $\mathrm{CM}(\mathrm{GxA})$ indicando buena adaptación general a los ambientes estudiados, aunque si se considera que la selección se basa solamente en el valor de Pi y que tal parámetro representa el cuadrado medio del efecto conjunto de variedades y la interacción $\mathrm{G} \times \mathrm{A}$, se podría correr el riesgo de descartar un genotipo que muestre poca adaptabilidad general pero sobresaliente en adaptación específica, ya que el valor de Pi representa la superioridad en el sentido de adaptabilidad (Lin y Binns, 1988).

\section{Conclusiones}

De acuerdo con los datos agronómicos, fitopatológicos, de calidad industrial y estabilidad del rendimiento, las variedades liberadas para condiciones de riego en El Bajío desirable genotypes would be those with higher yield and lower coefficient of variation. The variety Chicalote " $\mathrm{S}$ " is the most stable, followed by Rebeca F2000, Náhuatl F2000, Pastor F2000, Triunfo F2004 and Tlaxcala F2000 (Table 6). The stability parameters of Eberhart and Russell (1966) resulted in regression coefficients lower than the unit in the varieties Salamanca S75, Barcenas S2002, Zacatecas VT74, Eneida F94, and Pavon M87, indicating that these varieties present a relative adaptation to unfavorable environments (Rodríguez et al. 2002).

Ten varieties had values of 0.96 to 1.05 , and were therefore considered as genotypes with stable yields across environments and years, while varieties Romoga F96, Triunfo F2004, Batan F96, Gálvez M87 and Náhuatl F2000 had regression coefficients greater than the unit, indicating that these varieties respond positively to environmental improvements of production. The variances of the deviations of regression $\left(\mathrm{S}^{2} \mathrm{di}\right)$ showed, in all cases, to be different from zero, indicating that the linear model is not appropriate to describe the response of the genotypes as a function of the environmental effect, as, according to this criterion, the genotypes are not stable due to unpredictable variations. Nine varieties had the lowest values of this parameter, among which stand out Náhuatl F2000, Temporalera M87, Tlaxcala F2000, Triunfo F2004, Gálvez M87, and Juchi F2000.

According to the parameters of superiority of Lin and Binns (1988), the most stable genotypes were those with small values of $\mathrm{Pi}$, such as the varieties Chicalote "S", Rebeca F2000, Náhuatl F2000, Pastor F2000, Triunfo F2004, and Tlaxcala F2000, a classification which coincided with the one obtained through the coefficient of variation of Francis and Kannenberg (1978); these varieties were also those that showed the highest yields, exceeding by a wide margin the overall average.

Furthermore, from the analysis of these indexes it can be seen that these varieties presented a behavior parallel to the maximal response across environments; these varieties are the ones with the highest yields, so the index assigns stability to high yields. In addition, these varieties showed lowervalues of the parameter $\mathrm{CM}(\mathrm{GxA})$, indicating a good overall adaptation to the environments studied, although considering that the selection is based solely on the value of $\mathrm{Pi}$ and that this parameter represents the mean square of the combined effect of varieties and the interaction $\mathrm{G} \times \mathrm{E}$, it could be possible to discard a genotype that shows generally 
como son Bárcenas S2002, Cortazar S94, Salamanca S75, Eneida F94, y las variedades Zacatecas VT74, Juchi F2000, Finsi F2000, Era F2000, Gálvez M87, Pavón F76, Batán F96 yTemporalera M87, mostraron una serie de inconvenientes en las siembras detemporal en el Estado de México, por lo que no es recomendable seguirlas utilizando en siembras comerciales. Las variedades que mostraron buenos resultados en las condiciones de temporal evaluadas y que sí es recomendable utilizarlas en siembras comerciales son Tlaxcala F2000, Triunfo F2004, Náhuatl F2000, Rebeca F2000, Tollocan F05 y Romoga F96, tanto por sus altos rendimientos y buena estabilidad como por su resistencia a royas y al complejo de enfermedades foliares. La línea experimental Chicalote "S" destacó por su alta productividad, buena estabilidad y resistencia a royas, siendo en general el mejor genotipo.

Entre las variedades se encontró variabilidad baja en variables como peso hectolítrico $(\mathrm{PH})$, dureza de grano (DG), rendimiento harinero (Rhr) y proteína en grano (PG), por lo que es conveniente contar con mayor variabilidad en esas característica en el cultivo de trigo. En variables de alveograma, fuerza del gluten (W), la variabilidad fue alta y aceptable, ubicando a las variedades sobresalientes como de gluten medio fuerte a fuerte, mientras que las variables de calidad panadera índice de tenacidad (T/L) y volumen de pan (VP) presentaron mayor variabilidad.

\section{Literatura citada}

American Association of Cereal Chemists (AACC). 1995. Approved methods of the AACC. $9^{\text {th }}$ edition. AACC. St. Paul, MN, USA. $1269 \mathrm{p}$.

American Association of Cereal Chemist. (AACC). 2000. Approved methods of the AACC. $10^{\text {th }}$ edition. AACC, St. Paul, MN, USA.

Crossa, J. 1990. Statistical analysis of multilocation trials. Advance in Agronomy. 44:55-85.

Eberhart, S. A. and Russell, W. A. 1966. Stability parameters for comparing varieties. Crop Sci. 6:36-40.

Espitia, R. E.; Peña, B. R. J.; Villaseñor, M. H. E.; Huerta, E. J. y Limón, O. A. 2003. Calidad industrial de trigos harineros mexicanos para temporal. I. Comparación de variedades y causas de la variación. Rev. Fitotec. Mex. 26(4):249-256.

Espitia, R. E.; Peña, B. R. J.; Villaseñor, M. H. E.; Huerta E. J. y Limón; O. A. 2004. Calidad industrial de trigos harineros mexicanos para temporal. II. Variabilidad genética y criterios de selección. Rev. Fitotec. Mex. 27(1):41-47.

Finlay, K. W. and Wilkinson, A. A. 1963. The analysis of adaptation in a plant-breeding program. Australian J.Agric. Res. 14:742-754.

Francis, T. R. and Kannenberg, L. W. 1978. Yield stability studies in short season maize. I. Adescriptive method for grouping genotypes. Canadian J. Plant Sci. 58:1029-1034. poor adaptability but outstanding specific adaptation, since the value of Pi represents superiority in the sense of adaptability (Lin and Binns, 1988).

\section{Conclusions}

According to the agronomic, phytopathological, industrial quality and performance stability data, the varieties released for irrigated conditions in El Bajío, such as Barcenas S2002, Cortazar S94, Salamanca S75, Eneida F94, and the varieties Zacatecas VT74, Juchi F2000, Finsi F2000, Era F2000, Gálvez M87, Pavon F76, Batan F96, and Temporalera M87, showed a number of problems when cultivated under rainfed conditions in the State of Mexico, so it is not advisable to continue their use in commercial plantings. The varieties that showed good results under the rainfed conditions evaluated and that should be recommended for commercial plantings are the Tlaxcala F2000, Triunfo F2004, Náhuatl F2000, Rebeca F2000, Tollocan F05, and Romoga F96, both for their high yields and good stability, as for their resistance to rusts and the foliar disease complex. The experimental line Chicalote "S" stood out for its high yield, good stability and resistance to rust, being generally the best genotype.

Among the varieties there was low variability in variables such as hectolitre weight (HW), grain hardness $(\mathrm{GH})$, flour yield (Rhr) and protein in grain (GP), so it would be desirable to have greater variability in these features for the cultivation of wheat. With respect to the alveogram variable, gluten strength (W), the variability was high and acceptable, and the outstanding varieties ranged from medium-strong to strong gluten, while in the bread quality varieties the tenacity index $(\mathrm{T} / \mathrm{L})$ and the bread volume (BV) showed greater variability.

End of the English version

Huerta, E. J. and Singh, R. P. 2000. Las royas del trigo. In: el trigo de temporal en México. Villaseñor, M. H. E. y Espitia, R. E. (Eds.) SAGAR, INIFAP, CIR-CENTRO y CEVAMEX. México. 231-251 pp.

Lin, C. S. and Binns, M. R. 1988. A superiority measure of cultivar performance for cultivar $\mathrm{x}$ location data. Canadian J. Plant Sci. 68:193-198.

Lin, C. S.; Binns, M. R. and Lefkovitch, L. P. 1986. Stability analysis: where do we stand? Crop Sci. 26:894-900.

López, B. L.; López, B. R. J.; Castillo J. E. and López, B. F. J. 2001. Effects of long-term tillage, crop rotation and nitrógeno fertillization on breaking-making quality of hard red spring wheat. Field Crop Res. 72:197-210. 
McIntosh, R. A. 1992. Close genetic linkage of genes conferring adult plant resistance to leaf rust and stripe rust in wheat. Plant Pathol. 41:523-527.

Milus, E. A. and Line, R. F. 1986. Gene action for inheritance of durable, high-temperature, adult plant resistance to stripe rust in wheat. Phytopathology. 76:435-441.

Peña, B. R. J.; Hernández, E. N.; Pérez,H.P.; Villaseñor, M. H. E.; Gómez, V. M. y Mendoza, L. A. 2008. Calidad de la cosecha de trigo en México; ciclo otoño-invierno 2006-2007. Publicación especial del CONASIST-CONATRIGO. 5-6 pp.

Rodríguez, G. Ma. F.; Huerta, E. J.; Villaseñor, M. H. E.; Sandoval, I. J. S. y Singh, R. P. 2010. Análisis de virulencia de la roya amarilla (Puccinia striiformis f. sp. tritici) del trigo (Triticum aestivum L.) en los Valles Altos de México. Agrociencia. 44(4):491-502.

Rodríguez, P. J. E.; Sahagún, C. J.; Villaseñor, M. H. E.; Molina, G. J. D. y Martínez, G. A. 2002. Estabilidad de siete variedades comerciales de trigo (Triticum aestivum L.) de temporal. Rev. Fitotec. Mex. 25(2):143-151.

Rodríguez, V. J. 2000. Principios del mejoramiento del trigo en México, 1939-1955. Agric. Téc. Méx. 26(1):99-107.

Roelfs,A.P.; Singh, R. P.y Saari,E.E. 1992. Las royas del trigo. CIMMYT. México, D.F. 81 pp.

Saari, E. E. and Prescott, J. M. 1975. A scale for appraising the foliar intensity of wheat disease. Plant Dis. Reporter. 59:377-380.

Statistical Analysis System (SAS) Institute. 1990. Statistical Analysis System. SAS/STAT. User's guide. Ver. 6 . Ed. SAS Institute, Inc. Cary, NC. 243 p.

Sayre, K. D.; Singh, R. P.; Huerta, E. J. and Rajaram, S. 1998. Genetic progress in reducing losses to leaf rust in CIMMYT-derived mexican spring wheat cultivars. Crop Sci. 38:654-659.

Serna, S. S. R. O. 1996. Química, almacenamiento e industrialización de los cereales. Ed. A. G. T. México. 521 p.

Shukla, G. K. 1972. Some statistical aspects of partitioning genotypeenvironmental components of variability. Heredity. 29(2):237-245.
Servicio de Información Agroalimentaria y Pesquera (SIAP). 2009 Anuario Estadístico de la Producción Agrícola 2009. www. siap.gob.mx. (consultado marzo, 2011).

Singh, R. P. 1991. Pathogenicity variations of Puccinia recondita f. sp. tritici and $P$. graminis f. sp. tritici. In: wheat-growing areas of Mexico during 1988 and 1989. Plant Dis. 75:790-794.

Singh, R. P.; Huerta E. J. and Rajaram, S. 2000. Achieving near-immunity to leaf and stripe rusts in wheat by combining slow rusting resistance genes. Acta Phytopathol. Entomol. Hungarica. 35:133-139.

Singh, R. P.; Huerta, E. J.; Figueroa, P. L. and Pfeiffer, W. 2004. Ocurrence and impact of a new leaf rust race on durum wheat in the Nothwestern Mexico during 2001-2002. Plant Dis. 87:230-236.

Slafer, G. A.; Calderini, D. F.; and Miralles, D. J. 1996. Yield components and compensation in wheat: Opportunities for further increasing yield potential. In: increasing yield potential in wheat: breaking the barriers. Reynolds, M. P.; Rajaram, S.; McNab, A. (eds). México, D. F. CIMMYT. 101-133 pp.

Solís, M. E.; Hernández, M. M.; Borodanenko, A.; Aguilar, A. J. L. y Grajeda, C. O. A. 2004. Duración de la etapa reproductiva y el rendimiento del trigo. Rev. Fitotec. Mex. 27(4):323-332.

Tai, G. C. C. 1971. Genotypic stability analysis and its application on potato regional trials. Crop Sci. 11:184-190.

Turrent, F. A.; Moreno, G. R.; Villaseñor, M. H. E.; Alemán, F.; Moreno, R. D.; Aveldaño, R. y Salazar, A. 1992. Manual de diagnóstico y recomendación para el cultivo de trigo en el Estado de México. Chapingo, Estado de México. México, SARH, INIFAP, CEVAMEX. (Publicación especial Núm. 5). $136 \mathrm{p}$.

Villaseñor, M. H. E. y Espitia, R. E. 2000. Variedades de trigo recomendadas para siembras de temporal en México. In: el trigo de temporal en México. Villaseñor, M. H. E. y Espitia, R. E. INIFAP, CIR-Centro, CEVAMEX. 151-176 pp. 